Александра Весић

Универзитет у Београду

Филолошки факултет

vsaska94@gmail.com
УДК 821.161.1.09-32"19"

https://doi.org/10.18485/slavistika.2020.24.1.18

Оригинални научни рад примљено 29.04.2020.

прихваћено за штампу 21.05.2020.

\title{
ИНТЕРТЕКСТУАЛНЕ ТЕОРИЈЕ НА ПРИМЕРУ „ПРИЧА СА КОЛИМЕ” ВАРЛАМА ШАЛАМОВА
}

Овај рад кроз призму интертекстуалности проучава поетику Варлама Шаламова и анализира причу „На вересију” из збирке „Приче са Колиме”. Кроз анализу приче се описују интертекстуалне појаве и на примерима се показује којим се све интертекстуалним врстама служи аутор како би представио свој поетски свет.

Кључне речи: интертекстуалност, Шаламов, руска књижевност XX века, документаризам, „Приче са Колиме”, неграматичност, пародија.

This work studies the poetics of Varlam Shalamov through the prism of intertextuality and analyzes the story "On credit" from the collection "Kolyma Tales". Through the analysis of history, intertextual phenomena are described, and examples show how all intertextual types serve the author to represent his poetic world.

Keywords: intertextuality, Shalamov, Russian literature of the XX century, the documentary, "Kolyma tales", ungrammaticality, parody.

Средином шездесетих година XX века формирао се нов, модеран, граничан и трансгресиван појам, који је обликовао нове погледе на литературу и њену специфичност, на природу стваралаштва, на постојање, смисао, технику, структуру и жанровске одлике текста, а пре свега на улоге аутора и читаоца, а то је интертекстуалност. Значење израза „интертекстуалност“ не можемо адекватно објаснити етимологијом, јер га је тек између 1966. и 1974. прва сковала, дефинисала и увела у семиотику и науку о књижевности Јулија Кристева (Юлия Кръстева) (Јуван 2013: 7-10) као замену за Бахтинов појам интерсубјективности. Кристева се у својим текстовима „Бахтин, реч, дијалог и роман“ и „Проблеми структурисања текста“ ослања на дела књижевног теоретичара Михаила Бахтина и надовезује се на његову теорију дијалогичности и амбивалентности, истичући да сваки текст има два нивоа тумачења, хоризонтални, који повезује читаоца и аутора, док други ниво повезује текст са другим текстовима. Исто тако, књижевна структура не постоји сама од себе, већ се генерише у односу са другим структурама. Апсорпцијом и трансформацијом настаје нови текст као мозаик цитата, те пажњу треба усмерити ка ранијим текстовима који су условили настанак садашњег.

При одређивању и коришћењу појма интертекстуалности, прво треба споменути да је Хомер у „Илијади и Одисеји“ спојио у целину усмено-митолошко наслеђе, које је постојало дуго пре њега. Он је поменуто наслеђе фиксирао и дао му заокружен, репрезентативан епски облик, а потом је - такође уз помоћ нормативне поетике и граматичко-реторичке праксе - постао узор небројеним 
наследницима (Јуван 2013: 16). Поред евокације и усменог наслеђа, писци су се користили и текстуалним изворима својих претходника, и управо су ти односи међу текстовима омогућили стварање, обликовање и потребу за увођењем појма интертекстуалност. Посебно се књижевност у средњем веку ослањала на стриктне норме и ауторитете антике. У каснијем периоду се развио потпуно другачији однос према томе какво значење носи употреба интертекстуалности у стваралаштву. Иако је у постпросветитељској лепој књижевности појам зависности од норми потпуно потиснут, у широкој употреби су били цитати, чије је коришћење у ауторским текстовима било додатно наглашено, јер се тиме указивало на то колико је ауторова порука важна будући да постоји могућност да се ослони на већ неко афирмисано дело тј. аутора.

У овом раду ћемо покушати да опишемо интертекстуалне појаве у причи „На вересију“ руског писца Варлама Шаламова. Шаламов је 1929. због учешћа у тајној троцкистичкој групи ухапшен и као „социјално штетан елемент“ је осуђен на три године радно-поправног логора. Како 1937. године почиње други талас репресија, опет је ухапшен због „контрареволуционе троцкистичке делатности“" и овај пут проводи пет година у поправним логорима у Магадану и Колими. Осуђен је и трећи пут под оптужбом да је говорио позитивно о писцу-емигранту Буњину. Колиму је званично могао да напусти тек 1951. године, али је потпуну рехабилитацију и дозволу за повратак у Москву добио тек 1956. године. Након што је скоро трећину живота провео у логору, свој живот је посветио томе да истина не остане између логорских зидина заједно са свима који нису успели да се врате у „стварни живот“. Управо због таквог искуства, Шаламов даје јединствени печат својим делима и кроз интертекстуалност их повезује са историјом, друштвом и културом. По повратку у Москву, уз помоћ Пастернака постаје члан књижевних кругова и публика добија могућност да се упозна са његовим делима. Тако су и „Приче са Колиме” («Колымские рассказы») имале срећу да буду објављене, први пут тек 1966. године али не у Русији, већ на Западу. Приче из овог зборника о животу у логору излазе појединачно, па тако прве четири приче из зборника, на руском језику објављује „Нови часопис" у Њујорку. Када су 1978. године у Лондону „Приче са Колиме” биле коначно у целости објављене на руском језику, Шаламов је већ био тешко болестан али је са великом радошћу примио ту вест. Упокојивши се 1982. године, није дочекао објављивање ове збирке приповедака у својој домовини.

„Сопствена крв и сопствена судбина су потребни савременој књижевности” (Сиротинская 1998). А управо то проза Варлама Шаламова даје читаоцима XX века у „Причама са Колиме“, делу које је писао скоро двадесет година. У оквиру циклуса „Приче са Колиме” у периоду од 1954. до 1973. године настало је шест збирки: „Приче са Колиме”, „Лева обала”, „Уметник лопате”, „Есеји из света криминала”, „Васкрсење ариша” и „Рукавица или КР-2”.

„Сваки текст се гради као мозаик цитата, сваки текст је апсорпција и трансформација другог текста“ (Бахтин 1986: 258). И када говоримо о текстовима Шаламова и о „Причама са Колиме”, пре свега треба обратити пажњу на саму форму шестоделног циклуса и то какву целину граде на први поглед неповезани делићи. С обзиром да су га многи критиковали због стила писања, неповезаности и недоречености, Варлам Шаламов на све то одгова- 
ра писањем дела „О прози” 1965. године. У овом делу, Шаламов се не осврће само на одређивање онога шта су „Приче са Колиме”, већ износи свој став како о новим тенденцијама у књижевности, тако и о делима других писаца, наслеђу старог и тековинама новог времена. Описује постулате на којима се заснива естетика његовог уметничког документаризма. Сам прокламује своја убеђења да читаоцима више нису интересантна дела белетристике. „Читалац у данашње време може водити расправу само са документом и може се убедити само документом“ (Бахтин 1986: 258). А стављање читаоца у први план има значај, јер како се каже у делу „Интертекстуалност у поезији“: „Књижевност се изучава усмеравањем пажње на књижевни текст, уочавањем различитих начина његове перцепције“ (Бахтин 1986: 258). Шаламов је желео да се његов текст чита као реално доживљен догађај, желео је да читалац перципира слику логора као стварност коју је он документовао у „Причама са Колиме”. Проза схваћена као документ (или као нешто више од тога) би подстакла читаоце на размишљање о теми сећања, заборава и могућности понављања историје. Писац не жели своју прозу да дефинише као текст, као пуко „слово на папиру“ јер: „Савременом читаоцу су потребне само две речи да схвати о чему се у делу ради и није му потребан детаљан опис портрета, не треба му класичан развој сижеа итд. Читалац тражи решење животно важних питања, тражи одговоре о смислу живота, о везама уметности и живота" (Шаламов 2012: 87). И тада Шаламов поставља питање - да ли нова проза и текст треба да буду документ или она може бити нешто више од документа? Текст и интертекстуалност су нешто активно, стваралачко: „текст је продуктивност“, јер се деструкцијом и поновном конструкцијом надовезује на језик и зато што је „пермутација текстова, интертекстуалност: у простору текста укрштају се и неутрализују бројни искази узети из других текстова“ (Јуван 2013: 12). Или како каже Кристева: „Својим начином писања, које је уједно читање претходног или синхронијског књижевног корпуса, аутор живи у историји, а друштво се уписује у текст“ (Кръстева 1969: 181).

Проза Варлама Шаламова се само на прво читање чини као тривијално излагање чињеница и догађаја, иако су је неки критичари баш тако и доживљавали - не као књижевност, већ као документарне записе. Научници као што су Ирина Сиротинска (Ирина Сиротинская), Наум Лејдерман (Наум Лейдерман), Михаил Михеев (Михаил Михеев), који су се бавили животом и делом Варлама Шаламова у својим радовима подвлаче да се у његовим причама под привидном једноставношћу скрива вишепланска уметничка творевина. И ту можемо приметити интертекстуалну функцију, коју у „материјализованом“ облику можемо, како каже Јулија Кристева, да читамо на разним структурним нивоима сваког текста и која даје тексту његове историјске и социјалне координате. Потврђено је да је писац ради јачег утицаја на читаоца стремио да достигне ефекат документарности и једноставности, али је у исто време, више пута изјављивао да „Приче са Колиме“ нису ни документ, ни цртице, ни сећања: „Када ме питају шта пишем, ја одговарам: ја не пишем сећања. Нема никаквих сећања у „Причама са Колиме”. Ја не пишем ни приче - тачније, трудим се да не пишем причу, већ то што не би било књижевност. Није проза документ, већ проза пропаћена као документ” (Сиротинская 1998). 
Збирка „Приче са Колиме“, једно од најзначајнијих прозних дела Шаламова, садржи тридесет две приче које су на први поглед самосталне и међусобно не тако тесно повезане ни хронолошки, ни логички, ни нараторски. Међутим, када је сам писац говорио о композицији својих прича, нагласио је да је управо такав редослед неопходан да би се задржала целовитост и хронологија историје коју нам приповеда. Различите наративне перспективе доприносе утиску да су приче недовршене, неповезане и насумично поређане. Ипак, и поред свих тих чиниоца, слика логора обједињује збирку и наглашава јединство хронотопа које се примећује тек након схватања да ово може да буде извештај сведока логорског живота или дневнички записи. Како би се ухватила нит мисли аутоpa, од читаоца се очекује не само да буде начитан, већ и образован и да може пре свега да примети, а затим и примени на текст различите сигнале метатекста и интертекстуалних веза које писац успоставља уз помоћ различитих врста цитата, експлицитних и скривених, директних и индиректних наговештаја и реминисценција. „„Обичан“ или просечно упућен читалац уочава константе литерарности или универзалије тако што „открива да су речи које су на први поглед неповезане у ствари чланови исте парадигме“““ (Квас 2009: 174). А колико је битно познавати и повезивати стечена и нова знања показују и аутори зборника „Интертекстуалност и интермедијалност“ (1988), уводећи термин интермедијалност, коју описују као појаву при којој је познавање дела из једне уметности релевантно за познавање дела у другој врсти уметности (Ораић 1988: 132). Најочигледније знаке интертекста можемо видети у самим насловима неких од прича из збирке „Приче са Колиме”: „Шери-Бренди“, „Тужилац Јудеје“, „Калигула“, „Сергеј Јесењин и свет лопова“, „Атинске ноћи“... А како би се на конкретним примерима доказала интертекстуална игра Шаламова, ми ћемо анализирати неке од елемената приче „На вересију“.

Алузије, реминисценције, чак и пародирање другог текста само су неки од интертекстуалних елемената у збирци Варлама Шаламова. Основни механизам писаног текста, наглашава Рифатер, јесте меморија, и зато читање текста није декодирање суседних знакова у линеарној целини, већ „спаривање ових знакова насупрот симултаним сећањима похрањеним у парадигмама“ (Квас 2009: 194). Пример је већ у првој реченици приче, где се интертекст открива активирањем свести и меморије читаоца презименом главног јунака коњушара Наумова (чије презиме алудира на Пушкиновог јунака Нарумова). Иако Шаламов своју причу започиње скривеним цитирањем, без цитата, читаоцу је јасно стављено до знања на ког аутора и на које дело се имплицира на почетку приче „На вересију“. Чак и без претеране аналитичке способности, читалац лако може да локализује цитат и као извор одреди Александра Сергејевича Пушкина и његову „Пикову даму“. „Како у уметничкој, тако и у неуметничкој продукцији, рецимо у беседништву, било је карактеристично угледање на узорне, угледне или успешне текстове, уопштено раширених односно ауторитативних аргумената, архетипских или стереотипних мотива и слика, као и употреба, апликација, приређивање и цитирање таквих извора, полемика с њима, позивање на њих односно на њихове ауторе, одломке или садржинске елементе“ (Јуван 2013: 15). Тако се и Шаламов угледа на „сунце руске поезије“ и из Пушкинових дела користи стереотипни мотив картања, називајући га карташким мегданима. Како примећује Јухнова 
Ирина (Юхнова Ирина) у свом раду о „Пиковој дами“, Пушкин започиње своје дело следећом реченицом: „Картали се једном код Нарумова, коњичкога официpa y гарди. “(Пушкин 1948), а код Шаламова се тај почетак пародира следећом реченицом: „Картало се код коњушара Наумова“. И довољно је да читалац примети само пар слова разлике и мале неправилности које се називају конектори, а они су „неграматичности, јер је њихова функција да на ретроактивној равни читања текста укажу читаоцу како текст има смисао једино у оквиру интертекста. Између текста и његовог читаоца успоставља се интерактивни процес, интертекстуални механизам покренут неграматичношћу или конектором који указује на интертекст. Да би се уочио управо такав однос између речи које Корнелије Квас назива „интратекстуалним везама“, треба обратити пажњу на сваку семантичку или фонетску везу и сличност између речи или израза. Уочене сличности код Шаламова истовремено скрећу пажњу читаоца и на разлике које су суптилне али не и случајне и стога носе посебно значење за целу причу. Многи познаваоци стваралаштва Варлама Шаламова, истичу иронију као једну од препознатљивијих стилских одлика писања и размишљања самог писца. Тако се поређење са Пушкиновим делом не може сматрати за случајност. Шаламов се служи једном од најпродуктивнијих и најстаријих интертекстуалних врста - пародијом, деградирајући коњичког официра у коњушара и не само што се пародирају ликови „Пикове даме“, већ се кроз Пушкина осликава очита паралела коју Варлам Шаламов жели да повуче између свог поетског система и „књижевности конвенције и клишеа“. Код Шаламова пародијски смех је имао за циљ да критикује дотадашње жанрове и дела и да прикаже њихову једнострану представу ствари. Исто тако, шта је Пушкину изгледало незамисливо са етичке тачке гледишта, Шаламову постаје норма и реалност.

Парафразирање „Пикове даме“ служи као детерминатор приче, одређујући га у очима читаоца као опис судбинског играња карата или како то приповедач још назива „карташких окршаја“. Поред „Пикове даме“, Пушкин своју пасију према картама описује и у „Евгенију Оњегину“. Јуриј Лотман у „Беседама о руској култури“ наводи делове „Евгенија Оњегина““ (допуна XVII строфе II главе) који се појављују само у појединим издањима дела управо због тога што приказују страст Оњегина према картању и посебним врстама карташких игара. Лотман описује процес различитих игара и појашњава термине као што су „банкомат“, „пунтер“ или „бура”, који се појављују и у причи Шаламова: „То је био Севочка, чувени зналац терца, рауба и буре - три класичне карташке игре, надахнути тумач на хиљаде карташких правила, којих су се играчи на овом мегдану морали строго придржавати" (Шаламов 2012: 82). Иако врло популарне у Пушкиново време, карте су сматране за врсту порока:

„Занимале су њих и страсти

И сећо их се Евгеније

(Спасен од њине бурне власти)

Са уздахом што сету крије

Срећан је ко је за њих знао

Па их се најзад отресао, 
Срећнији ко их не познаје

И ко се врло ретко каје;

Ко растанцима љубав лечи,

Ко мржњу сплетком утољава

И с другом и са женом зева

Без љубоморе и злих речи...

Срећан, ко карти своја права

На наслеђе не поверава“ (Пушкин 2016: 51).

Значај теме картања добија посебан значај ако се зна да су затвореницима одузимали оловке приликом провере примљених пакета, не само да се не би израђивала лажна документа, већ и да би се „уништило све што може да конкурише државном монополу карата" (Шаламов 2012: 81). Међутим, затвореници у причи Шаламова су мајстори заната и познају уметност и занат израде карата чак и од најлошије хартије и строго поштују установљена правила игре. „Вештина ручне израде карата спадала је у програм „витешког” васпитања младог криминалца" (Шаламов 2012: 81). Од мистичног феномена и елемента субкултуре руског двора, Шаламов картање спушта и убраја у део свакодневице најнижег слоја друштва - робијаша. И постаје игра живота и смрти. Или како Јуриј Лотман каже: „карташка игра док постаје језик на који су се преводиле различите појаве унутрашњег света јунака, активно моделује и утиче на слику о самом објекту. А објекат о коме се формирала слика код читаоца је сам живот у логору“ (Лотман 1992). У логору карташка игра није обично картање, него „робијашки карташки мегдани”, а „окршај не може да се заврши докле год супарник може још нечим да „одговори”” или до смрти, како је то било правило и у двобојима. Ако играју двојица, знало се да су то мајстори. Положај у картању је означавао и положај у хијерархији затвореника. „Нико од мајстора није се понижавао да учествује у групним играма” (Шаламов 2012: 82). И приказавши само једно картање, Шаламов показује каква је била логорска хијерархија и каква су правила важила код „поштених лопова”.

Осим интертекстуалних веза са Пушкином, Шаламов указује на још једног руског писца, чији се стихови директно цитирају у причи „На вересију”:

„Како смо мало путева превалили,

како много грешака починили" (Шаламов 2012: 83).

Овим стиховима Шаламов повезује причу „На вересију” са причом „Сергеј Јесењин и свет лопова", које се налазе у истој збирци и у којима се велича једини песник којег „свет кажњеника” канонизује. Повезивањем ове две приче, Шаламов показује људску страну затвореника и тренутке у којима се види да и поред тога што се књиге десакрализују и што се од романа праве карте, постоје стихови који се поштују чак и у круговима криминалаца. Познато је да је Сергеј Јесењин био симпатизер криминалног света и самим тим што је криминалце посматрао пре свега као људе, задобио је симпатије затвореника, који су њему у част тетовирали стихове о слободи, женама, мајкама... Познавање стихо- 
ва Јесењина је био знак распознавања међу криминалцима, исто као и ношење крстића. У анализираној причи имамо слику логораша који као знак међусобног распознавања носе алуминијумске крстиће, а онда већ у следећој сцени се идеја Христа (као што Шаламов ради и са свим осталим књижевним и културним реалијама) своди на ниво логораша који на крст урезују женска тела или симболе карата. Све свето и узвишено је представљено као елемент живота у коме је циљ преживети ноћ. И зато када анализирамо Шаламовљева дела „треба се потрудити да не занемаримо оне димензије интертекстуалности које писмо повезују са субјектом, културом, друштвом и историјом“ (Јуван 2013: 9). По Шаламову треба писати тако да читаоци поверују у истинитост приче која је као жив документ, где аутор и чији творац није само пуки посматрач већ активни учесник живота. „Нова проза је сам догађај, битка, а не њен опис” (Шаламов 2004).

Кроз приповедање Шаламова се осећа доминација неутралног наратива и фокус је на објекту слике, меша се ауторска и јунакова тачка гледишта и немогуће постаје стварно. Из анализе само ове једне приче, можемо закључити да се у збирци Варлама Шаламова може наћи и потенцијални и актуелни интертекст и да он пише и за „обичног“ читаоца и за књижевног критичара. Свака прича може да представља засебну целину, а може се посматрати и као неодвојиви део низа који додатним познавањем књижевности и књижевних дела открива нове нивое формално-значењске структурираности.

Управо интертекстуалне везе формирају групе значења које образују дубок садржај прича и управо се кроз интертекст открива нови слој у причи коју аутор покушава да нам исприча. Можемо закључити да Шаламов кроз сложен интерактивни систем семантичких значења у фокус ставља самог читаоца, остављајући му избор да сам одлучи до ког нивоа текста ће да иде његово тумачење.

Овај рад је само путоказ за многобројне анализе дела Варлама Шаламова и уочавање интертекстуалности кроз коју се може тумачити читаво стваралаштво писца. Шаламов своја дела намењује активном читаоцу и очекује од њега да текстове чита тако да уочи аналогију између њих, тј. да користи интертекстуално читање, јер свака перцепција гради свој другачији лични смисао. Шаламов не намеће своје ставове, али одређује тему која може, али и не мора да оствари утицај на читаоца, а читаоцу оставља интертекст као неопходан кључ за нова тумачења.

\section{Цитирана литература}

Бахтин, Михаил. Эстетика словесного творчества. Походаев В. С. Москва: Искусство, 1986.

[Bakhtin, Mikhail. Ėstetika slovesnogo tvorchestva. Pokhodaev V. S. Moskva: Iskusstvo, 1986]

Јуван, Марко. Интертекстуалност. Нови Сад: Академска књига, 2013.

[Juvan, Marko. Intertekstualnost. Novi Sad: Akademska knjiga, 2013]

Квас, Корнелије. Интертекстуалност у поезији. Београд: Завод за уџбенике, 2006.

[Kvas, Kornelije. Intertekstualnost u poeziji. Beograd: Zavod za udžbenike, 2006]

Кръстева, Юлия. Semeiotike: Recherches pour une semanalyse. Париж: 1969.

[Krasteva, YUliya. Semeiotike: Recherches pour une semanalyse. Parizh: 1969]

Лотман, Юрий. Культура и взрыв. Москва: Гнозис, 1992. 
[Lotman, IOriĭ. Kul'tura i vzryv. Moskva: Gnozis, 1992]

Лотман, Юрий. Роман А.С.Пушкина «Евгений Онегин». Комментарии. Ленинград: Просвещение, 1983, <http://pushkin-lit.ru/pushkin/articles/lotman/onegin-kommentarij/ onegin-comments-ot-sostavitelya.htm> 3.6.2020.

[Lotman, IUriì. Roman A.S.Pushkina «Evgeniī Onegin». Kommentarii. Leningrad: Prosveshchenie, 1983, <http://pushkin-lit.ru/pushkin/articles/lotman/onegin-kommentarij/onegin -comments-ot-sostavitelya.htm> 3.6.2020]

Ораић, Дубравка. „Цитатност - експлицитна интертекстуалност”. [В:] 3. Маковић и др. (ур.) Интертекстуалност и интермедијалност. Загреб: Завод за знаност о књижевности, 1988, 121-156.

[Oraić, Dubravka. „Citatnost - eksplicitna intertekstualnost”. [V:] Z. Maković I dr. (ur.) Intertekstualnost i intermedijalnost. Zagreb: Zavod za znanost o književnosti, 1988, 121-156]

Пушкин, Александр Сергејевич. Евгеније Оњегин. Београд: Партенон. 2016.

[Puškin, Aleksandr Sergejevič. Evgenije Onjegin. Beograd: Partenon. 2016]

Сиротинская, Ирина, подгот. текста. Собрание сочинений: В 4-х т. Москва: ВАГРИУС, 1998, <https://shalamov.ru/library/21/45.html > 3.2.2020.

[Sirotinskaiâ, Irina, podgot. teksta. Sobranie sochineniǐ: V 4-kh t. Moskva: VAGRIUS, 1998, <https://shalamov.ru/library/21/45.html > 3.2.2020]

Пушкин, Александр. Полное собрание сочинений: В 16 т. Москва: Издательство AH CCCP, 1937-1959. Т. 8, кн. 1. 1948.

[Pushkin, Aleksandr. Polnoe sobranie sochineniǐ: V 16 t. Moskva: Izdatel'stvo AN SSSR, 1937-1959. T. 8, kn. 1. 1948]

Шаламов, Варлам. Приче са Колиме. Београд: Лом, 2012.

[Šalamov, Varlam. Priče sa Kolime. Beograd: Lom, 2012]

Шаламов, Варлам. Новая книга: Воспоминания. Записные книжки. Переписка. Следственные дела. Москва: Эксмо, 2004, <https://shalamov.ru/library/24/59. $\mathrm{html}>3.2 .2020$.

[SHalamov, Varlam. Novaiākniga: Vospominaniiā.Zapisnye knizhki. Perepiska. Sledstvennye dela. Moskva: Ėksmo, 2004, <https://shalamov.ru/library/24/59.html> 3.2.2020]

\section{Александра Весич}

\section{ИНТЕРТЕКСТУАЛЬНЫЕ ТЕОРИИ В «КОЛЫМСКИХ РАССКАЗАХ» ВАРЛАМА ШАЛАМОВА}

\section{Резюме}

В данной работе сквозь призму интертекстуальности изучается поэтика Варлама Шаламова и анализируется рассказ «На представку» из сборника «Колымские рассказы». Исходя из анализа рассказа описываются межтекстовые явления. На конкретных примерах показано, каким образом все виды межтекстовых взаимодействий служат автору для представления собственного поэтического мира.

Ключевые слова: интертекстуальность, Шаламов, русская литература XX века, документализм, «Колымские рассказы», неграмматичность, пародия. 